\title{
The Use of the Smartphone, A Nice Paradox: Functional and Dysfunctional at the Same Time
}

\author{
Vaccaro $\mathbf{M}^{1,2 *}$ \\ ${ }^{1}$ IESCUM, European Institute for the Study of Human Behavior, Italy \\ ${ }^{2}$ Associazione un mondo in $3 \mathrm{~d}$, Italy
}

*Corresponding author: Marianna Vaccaro, Ph.D, IESCUM, European Institute for the Study

\section{Review Article \\ Volume 4 Issue 2}

Received Date: March 15, 2020

Published Date: March 30, 2020

DOI: $10.23880 /$ eoij-16000230

of Human Behavior, Italy, Email: marianna.vaccaro@yahoo.it

\section{Abstract}

Article's aim is to create a parallel between the functionality and the dysfunctionality in the use of the smartphone to prevent abuse of the device. The increase in the frequency of use of the smartphone appears as a physiological reaction to technological progress but at the same time it seems to appear as a "paradox effect". On one hand, the presence of the smartphone improved human communication in distance and speed. It helped personal and relational growth. On other hand, it has made all personal data public, traceable at any time and in context, increasing the fragility of the human being. It becomes an effective stimulus to modify the relationships and biological balance of the human organism, but the abuse of the smartphone today leads to talk about addiction. It is important get to the bottom of to emerging data in the literature to prevent it.

Keywords: Smartphone; Functional; Behavior; Dysfunctional; Addiction

\section{Introduction}

The smartphone, born as an evolution of the portable phone, gained considerable importance in the lives of many people and their activities, but with a negative impact on freedom of choice, motivation and commitment in many areas of the daily life: study, interpersonal relationships, personal culture and so on.

The risks associated with the diffusion of smartphones do not depend on the device itself, but on how and how much both young people and adults depend on it [1-6].

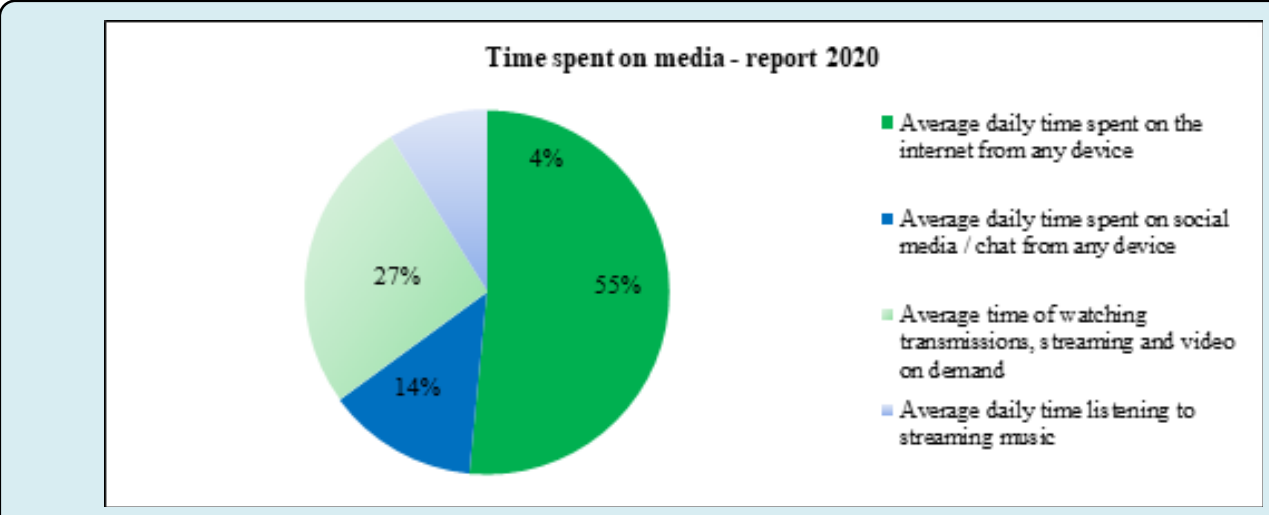

Figure 1: The graph shows the Italians average time using the media (We Are Social, 2020). 
The latest data from the surveys conducted by We Are Social (2020) in collaboration with Hootsuite, a social media management platform that collects data about the use of social channels, mobile devices and everything related to the digital world both globally and in individual markets, show that on average each user spends about 6 hours a day online (almost twice $\mathrm{w}$ the time spent in front of the TV). Smartphone users go online more than 80 times a day, which means they use their device approximately every 12 minutes (Figure 1).

Although it is mainly widespread among the youngest, it is also widely used by adults and the elderly [6-8]. The smartphone is something "They could not live without" (Smith, 2015). The average frequency with which A person controls its device about 34 times a day, on average, for no specific reason, simply out of habit [9].

In Australia, children spend over five hours a day on their device with the consequent accumulation of emotional stress, relationship issues and improper use of the language in their text messages [10].

In the rest of the world, it is used from six to nine hours a day [11-13]: this is because the smartphone is considered an important extension of himself [14], whereby many young people today find it difficult to imagine their own life without its presence. The easy access almost everyone has to social media has made this problem even more serious, because it reduces awareness of the amount of time spent surfing the
Internet or chatting, with serious repercussions in many areas, from the level of academic performance to social interaction [15]. For example, an interview [16] made to 100 Swedish students on the use of Facebook showed that $85 \%$ use the platform at least once a day and spend an average of 75 minutes on Facebook, considered essential to maintaining social relationships. It is not only the amount of time spent online that needs to be considered, but also how this is spent. For example, in the United States from an interview with a sample of 1,605 subjects between the ages of 18 and 54, it was found that mainly people log in to Facebook before going to the bathroom, immediately in the morning as soon as you are awake and in the middle of the night [17]. The desire of users to always be present on social networks is greater than the need to sleep [18]. A study conducted by Junco [19] on a group of 1,839 university students showed that $92 \%$ of use Facebook for about 102 minutes a day and login to the social network at least six times, while $60 \%$ admit that they are addicted to their devices. Studies conducted by David and colleagues [20] show that $81 \%$ of users keep their devices nearby for the whole day and control them, on average, 110 times a day.

The mode and frequency of use of the smartphone differ according to gender [21-25]. Women use their devices more than men $[21,22,26-30]$ because they are more interested in following what happens on Facebook, Instagram, and other social platforms, and in sending messages or e-mails (Figure 2).

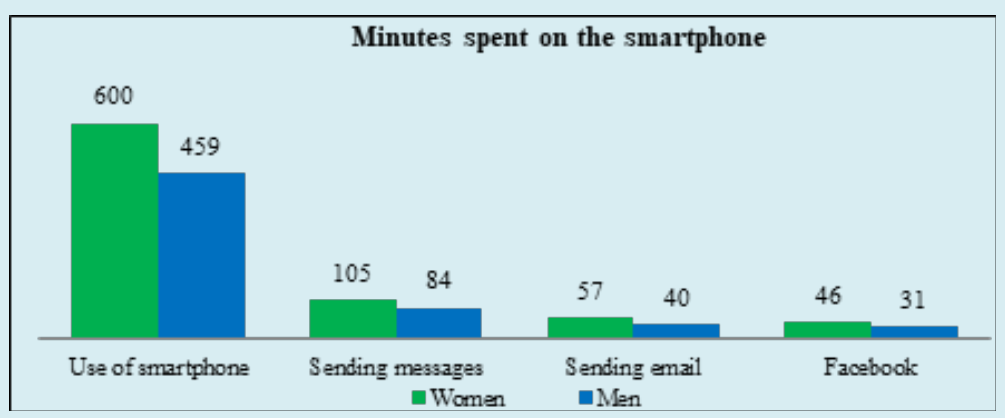

Figure 2: The graph shows the average minutes spent using the smartphone, based on gender differences [13].

Men use it as an entertainment tool [13,31] or information [32], while women as a device for improving or starting new relationships [33-35].

The use of the smartphone, according to Mick and Fournier (1998), is a good example of a "paradox of technology". Compared to the undoubted advantages that it has brought to the management of many activities, we can list as many negative aspects that are being highlighted in key areas of education, culture, and sociality.

\section{Functionality of use of the Smartphone}

\section{Coordinate Communication}

The device is so versatile that it be used for many functions: from a practical point of view, it is optimal in emergencies, for the organization of transport and in the 
location of public and private places [36,37]. In the field of public health, it has improved the quality of professional communication in the health sector [38-40] and allowed to better monitor the infrastructures [41,42]. Finally, it served to increase the socialization of adults and children with disabilities [43] or autistic [44]. The presence and widespread use of the smartphone has undoubtedly revolutionized the relationships between groups of peers, colleagues and family members [45]. Having the device always with you allowed parents to monitor the movements of their children and to be always in contact with them $[46,47]$, guiding them even remotely in the choices or supporting them in carrying out specific activities. In companies, it has increased the commercial development and it speeded up communication between managers and employees or between managers and suppliers [48].

\section{It Stimulates Learning}

Furthermore, it has improved the coordination of educational activities and the exchange of information between educational sectors such as school and family. The presence on the online chat makes the members of different groups collaborating and facilitates the exchange of notes or the support between colleagues in the achievement of their tasks, even if they are many kilometers away, and it also favours academic success [49-52]. Besides, it allows you to participate remotely in training courses, as teachers or users [53], and to be constantly updated on training offers [54].

\section{It Promotes Socialization and Personal Growth}

The different prices on the market allow anyone to own a smartphone and to be able to use it at any time and place to expand their social relationships and maintain or improve contacts with friends and family [55-61], thus promoting a deeper bond between family members [62] and reducing the feeling of loneliness [63].

By young people, it is now considered a fundamental tool for their social achievement [64-66]. Contacting and confronting others promotes a sense of autonomy, personal identity, and self-esteem [67-73]. Those who suffer from low self-esteem are more likely to use their device to feel in touch with the members of their social group, probably because through social media, they do not expose themselves directly and can create more relationships and increase their sense of security [74]. You can engage socially either formally, for example by joining an association or club, or informally, as happens in a group of friends [5-78], either way, it is an important thing for young people because the sense of belonging to a community is a growth factor and affects their social well-being, self-efficacy, and socialization $[79,80]$. In this sense, the use of social media offers more opportunities to participate in different social activities, provides functionality and communication spaces in which you come in contact with many people, from various backgrounds, with an expansion of knowledge and ways of thinking, and enrichment concerning one's small world $[81,82]$.

People are more likely to create relationships by making more calls, but those who are shyer prefer sending messages [83], however both ways are related to the need to create and keep relationships alive. A research conducted by Mc Coy [84], on a sample of 777 students, has tried to understand what are the stimuli to use the smartphone in the school context for non-academic purposes: it has emerged that the majority use it to fight boredom and to be in contact with the surrounding world at any moment.

The functional elements treated so far have, however, over time become a double-edged sword: just think of how parents in monitoring the movements of their children indirectly end up exercising a form of control. The mode and the high frequency of the use of the device have changed habits, values, family relationships and social interactions in individual people and the whole community $[85,86]$. All this has paradoxically diminished direct contact with family and friends and has led human beings to experience feelings of loneliness and depression [87] or isolation. People feel compelled to be always available and to communicate their status, wherever they are Bachen, et al. and Choliz $[88,89]$.

\section{Dysfunctionality of Use of the Smartphone}

\section{It is Traceable Everywhere}

Being always connected and easily reachable without paying attention to the time or context has contributed to making everything urgent, at all times and in all places, and this entails excessive social pressure to which we must respond with commitment and responsiveness without limits. The availability of SMS, e-mails, or voice messages through smartphones implicitly requires quick and immediate reading and response. Unlike computers that are turned off at some point, smartphones are brought everywhere, as they're "mobile", including places generally considered "private" such as the bedroom [90], or during breaks and convivial moments such as dinner, lunch or an aperitif. They are the first thing we look at in the morning when we wake up, and the last thing before bed [91].

\section{Everything is Public}

The use of social networks, such as Facebook, pushes to establish many more online relationships and to make public their image and personal life [92], with the consequence of feeding and spreading a certain tendency to narcissism 
[93-95]. The photos shared on social networks immortalize moments of pure fun but at the same time intimate moments that with a click are available for the entire community on the net. Oral or written conversations, whether trivial or important, have also become much more public, completely shifting the boundaries of intimacy from previous decades. The response and support that is immediately obtained through electronic communication act as reinforcements that increase the frequency with which people tend to write something or share news online [96-99].

\section{Emotions and Meanings get Confused}

In the research conducted by Lundquist, Lefebvre, and Garramone [100], one of the major problems reported by the participants concerns the inability to correctly interpret emotions during the reception of SMS, e-mail and posts on social networks. Since these messages deliver only content, but not the emotional tones transmitted by the vocal messages, one is not always sure of what the messages intended to communicate. "I think smartphones can hinder direct communication, negatively affect grammar skills and reduce the time spent face to face with others," said one interviewee. Using technology to express ideas or moods can be the origin of misunderstandings, often linked to the fact that the recipients cannot listen to the other person's tone of voice and thus understand if the message is ironic or serious. This leads to unpleasant or conflicting situations and, why not, also unnecessary stress.

\section{Creates Human Frailty}

Nowadays the number of friends on Facebook is considered particularly significant in the person's life; consequently, the actual network of relationships in real life is implicitly put into the background. This adds up to another element of ontological fragility, the lack of "redundancy": using almost exclusively the digital medium effectively deprives the individual of the opportunity to experience the various facets of reality in its concreteness, to deal with sudden and external stresses, which is necessary for the personal growth and improvement in terms of adaptation and flexibility. Interacting with the social dimension mainly through the technological medium can not only make the individual extremely fragile but can even become indispensable for those people who are not ready to face a sudden event, a black swan [101], which can unexpectedly cause skip their safety net.

People immerse themselves in virtual communication to avoid negative feelings and moods, loneliness, anxiety and boredom $[102,103]$ or to escape uninteresting conversations [104], but, on the other side, online contact has led many to greater isolation in real life and too weak relationships
[105]. This way of carrying on relationships and reacting to stimuli from the environment leads to a decreased ability to understand and perceive the other, thus missing the real interaction that involves all the senses, pillars of empathy.

\section{From Support to Substitute for Choices}

The choice to always be online has given digital natives the feeling of being more capable of exercising power over things and events. To give some examples, if you lose your smartphone, thanks to the GPS signal you can locate it, or in a place where there are few means of transportation an internet connection allows you to locate the closest car of the car-sharing service. By staying connected, you can get directions, make appointments, check your finances, book trips, shop, shop for food, and so on. In reality, despite the apparent feeling of control, these behaviours are leading in a direction contrary to the principles of personal safety [106] and this is not surprising: technology and data confirm us who we are and guide us on the most familiar routes, anchoring us in our comfort zone, rather than pushing us, when we have to make a choice, to discover the pros and cons independently. Thus digital devices, ways of accessing the reality of the network, instead of being only media become substitutes for our choices.

\section{There is Anxiety about Control}

Control anxiety is a potential risk factor, which can generate behavioural disturbances, and arises when a compulsive behaviour such as that which makes the device use and controls the apps is implemented to avoid negative experiences. Some apps created for communication (e.g. WhatsApp, which allows you to control the access of each user) contribute to perverse relationships and facilitate the tendency to hyper-control: "What is he doing? Who are you chatting with, if you're not writing to me? Why is she still awake? Why don't you write to me? "The technological medium favours control strategies, which represent an opportunity in the very short term (for example, I always know what my partner is doing, where my friends are, etc.), but they are instead a serious problem in the medium-long term. The impossibility of not constantly monitoring the activities of others can make people feel lost, disoriented, unstable, overwhelmed, and consequently, they act in an uncontrolled and dangerous way for others). This excess of control that arises to avoid negative internal experiences is called "experiential avoidance" and translates into all those strategies that are put in place to remove emotions and feelings that are difficult to deal with from oneself while preventing the pursuit of others more significant and vital objectives.

In recent researches on thought and language, such 
as ACT - Acceptance and Commitment Therapy [107] and Relational Frame Theory [108], it is highlighted that control strategy that should serve to eliminate personal discomforts, in some cases have a central role in exacerbating the physiological suffering associated with the human condition. Psychopathology would arise, therefore, when the most significant long-term goals, for example, the links with people or the affirmation of important values, are replaced by short-term goals, such as feeling good, looking good and to preserve, in the immediate future, one's conceptualized self. Guided by these short-term purposes, ephemeral by their nature, the behavioural patterns shrink and distance the individual from real values.

\section{Could the High use of the Smartphone be an Addiction?}

The immense use of the smartphone has been defined as "one of the greatest addictions on non-substances of the twenty-second century", induced both by the low cost of the device and by the many features it has, with important repercussions on the main existential areas, such as personal, relational, scholastic, domestic, emotional, and with the resulting modification of mood up to escape from reality. The addiction develops gradually, with a functional and facilitating use of numerous daily activities, such as shopping or searching online, finding an address, sending an urgent message, and so on; subsequently, its use can become excessive and turns into an addiction [109], when for example it replaces social contacts with Facebook visits, which are increasingly frequent and distracting.

The addiction process refers to the distinction between predilection and will. In other words, the smartphone user switches from liking their device to wanting it. This transition from pleasure to will is referred to as the "inflection-decline point". This turning point indicates a shift from the normal daily behaviour to addictive behaviour in which will has replaced pleasure as a motivating factor of behaviour. The authors argue that this behavioural form of addiction activates the same neural circuitry as substance addiction. Lundquist, Lefebvre, and Garramone based on the six criteria set by Brown $[110,111]$ conducted an investigation aimed at assessing how much getting a "like" on Facebook, or be added as a friend, or receiving a message, promoted a positive sense of well-being in the subject or generated relationship difficulties in personal, social and working life. The interviewees defined themselves as addicted to their smartphone as if the tool was glued to their hands; they also recognized as automatic behaviours like uploading images or sharing information with other people on the activities carried out throughout the day. One participant stated that it was unthinkable to follow a 50-minute lesson without texting or checking Facebook and that, when he was unable to control the smartphone, an anxiety sensation would come as if he had lost something. Others reported a sense of panic while not having it with them constantly and that they constantly checked it for the pleasure of seeing if there were new messages, even if they didn't receive any notification, and that, even though they were fully aware that Facebook news hadn't been updated in the past 5 minutes, however, they felt compelled to check anyway.

According to Wajcman \& Rose, smartphone addiction is because:

- It is always active.

- It is more available than the landline phone.

- Allows easy contact even with strangers.

To understand which activities carried out with the smartphone are most likely to lead to addiction, it is useful to refer to the learning process. When a behaviour is followed by "reinforcement", the behaviour is more likely to be reproduced. It is the "law of effect". Based on the principles of operating conditioning, when a user experiences feelings of satisfaction and/or enjoyment following a particular activity (for example watching a funny video, sent by a friend), he is more likely to undertake that particular activity again, which takes on the value of positive reinforcement [112]. The use of a particular smartphone function can also operate according to the principle of negative reinforcement (reduction or removal of an aversive stimulus). Pretending to answer a call, sending a message or controlling your device to avoid an embarrassing social situation, for example, are behaviours associated with negative reinforcement. Positive or negative refers only to the action of adding or removing something, but in both cases, it leads to an increase in the frequency and intensity of behaviour. Any activity that is reinforced, therefore, can be addictive [113-115].

Concerning the principles of learning, it is important to also consider the antecedents to explain what stimulates the frequency of use of smartphones. The instrument's features include personalized ringtones, incoming messages, and calls, compelling graphics or some tactile features (e.g. buttons, wheels, etc.); well, these features act both as antecedents and as reinforcements for the use of the device.

The 2015 report on mobile apps in the United States found that consumers spend up to $77 \%$ of the total time they spend on their mobile devices on applications on their smartphones [116]. Loose attachment to the smartphone is gradually leading to social withdrawal, the lack of tolerance, the difficulty in maintaining an adequate level of attention in carrying out the various daily activities and the disorder in the control of impulses [117]. Physically, those who compulsively use the Internet show different patterns of activity in regions of the brain that are involved in emotional 
and rewarding processes. They demonstrate a decrease in the volume of grey matter in many regions [118] and lower functional connectivity of the brain has been highlighted through magnetic resonance imaging. Anatomically, a study found reductions in the thickness of the cortex in the frontal orbit region among boys who are addicted to the Internet compared to boys who use it less [119].

Based on the above considerations, it would, therefore, be useful to sensitize the population to education in the use of the device, helping them to be more aware of the time they devote to smartphone-mediated activities and to push them to discriminate the real urgency of the information that comes from them, the functionality and its dysfunctionality. The literature [120-122] shows the effectiveness of psychoeducational interventions in addictions to nonsubstances.

\section{References}

1. Mick DG, Fournier S (1998) Paradoxes of technology: Consumer cognizance, emotions, and coping strategies. Journal of Consumer Research 25(2): 123-143.

2. Palen L, Salzman M, Youngs E (2001) Discovery and integration of mobile communications in everyday life. Personal and ubiquitous computing 5(2): 109-122.

3. Monk A, Carroll J, Parker S, Blythe M (2004) Why are mobile phones annoying? Behaviour \& Information Technology 23(1): 33-41.

4. Bianchi A, Phillips JG (2005) Psychological predictors of problem mobile phone use. Cyberpsychology \& Behavior 8(1): 39-51.

5. Paragas F (2005) Being mobile with the mobile: Cellular telephony and renegotiations of public transport as public sphere. In Mobile Communications, pp: 113-129.

6. Smith A (2012) The best (and worst) of mobile connectivity. Pew Internet \& American Life Project, pp: 30 .

7. Park N, Lee H (2012) Social implications of smartphone use: Korean college students' smartphone use and psychological well-being. Cyberpsychology, Behavior and Social Networking 15(9): 491-497.

8. Kim Y, Wang Y, Oh J (2016) Digital media use and social engagement: How social media and smartphone use influence social activities of college students. Cyberpsychology, Behavior, and Social Networking 19(4): 264-269.

9. Lee YK, Chang CT, Lin Y, Cheng ZH (2014) The dark side of smartphone usage: Psychological traits, compulsive behavior and technostress. Computers in Human Behavior 31: 373-383.

10. James D, Drennan J (2005) Exploring addictive consumption of mobile phone technology. In Australian and New Zealand Marketing Academy conference, Perth, Australia.

11. Lenhart A, Purcell K, Smith A, Zickuhr K (2010) Social Media \& Mobile Internet Use among Teens and Young Adults. Millennials. Pew internet \& American life project.

12. Demirci K, Akgönül M, Akpinar A (2015) Relationship of smartphone use severity with sleep quality, depression, and anxiety in university students. Journal of behavioral addictions 4(2): 85-92.

13. Roberts JA, Yaya LHP, Manolis C (2014) The invisible addiction: Cell-phone activities and addiction among male and female college students. Journal of Behavioral Addictions 3(4): 254-265.

14. Belk RW (1988) Possessions and the extended self. Journal of Consumer Research 15(2): 139-168.

15. Meena PS, Mittal PK, Solanki RK (2012) Problematic use of social networking sites among urban school going teenagers. Industrial Psychiatry Journal 21(2): 94-97.

16. Denti L, Barbopuolos I, Nilsson I, Holmberg L, Thulin M, et al. (2012) Sweden's largest Facebook study. Gothenburg Research Institute.

17. Guedes E, Sancassiani F, Carta MG, Campos C, Machado $S$, et al. (2016) Internet Addiction and Excessive Social Networks Use: What about Facebook? Clinical Practice \& Epidemiology in Mental Health 12(1): 43-48.

18. Hofmann W, Vohs KD, Baumeister RF (2012) What people desire, feel conflicted about, and try to resist in everyday life. Psychological science 23(6): 582-588.

19. Junco R (2011) Students spend a lot of time Facebooking, searching, and texting.

20. David ME, Roberts JA, Christenson B (2018) Too Much of a Good Thing: Investigating the Association between Actual Smartphone Use and Individual Well-Being. International Journal of Human-Computer Interaction 34(3): 265-275.

21. Billieux J, Linden MVD, Rochat L (2008) The role of impulsivity in actual and problematic use of the mobile phone. Applied Cognitive Psychology 22: 1195-1210.

22. Leung L (2008) Leisure boredom, sensation seeking, 
self-esteem, and addiction. Mediated interpersonal communication, pp: 359-381.

23. Junco R, Merson D, Salter DW (2010) The effect of gender, ethnicity, and income on college students' use of communication technologies. Cyberpsychology \& Behavior 13(6): 619-627.

24. Hakoama M, Hakoyama S (2011) The impact of cell phone use on social networking and development among college students. The American Association of Behavioral and Social Sciences Journal 15: 1-20.

25. Haverila MJ (2011) Cell phone feature functions and gender differences among college students. International Journal of Mobile Communications 9(4): 401-419.

26. Toda M, Monden K, Kubo K, Morimoto K (2006) Mobile phone dependence and health-related lifestyle of university students. Social Behavior and Personality: an international journal 34(10): 1277-1284.

27. Wei R, Lo VH (2006) Staying connected while on the move: Cell phone use and social connectedness. New Media \& Society 8(1): 53-72.

28. Jenaro C, Flores N, Gómez-Vela M, González-Gil F, Caballo C (2007) Problematic internet and cell-phone use: Psychological, behavioral, and health correlates. Addiction research \& theory 15(3): 309-320.

29. Jackson LA, Zhao Y, Kolenic III A, Fitzgerald HE, Harold $\mathrm{R}$, et al. (2008) Race, gender, and information technology use: The new digital divide. CyberPsychology \& Behavior 11(4): 437- 442.

30. Takao M, Takahashi S, Kitamura M (2009) Addictive Personality and Problematic Mobile Phone Use. Cyberpsychology \& Behavior 12(5): 501-507.

31. Junco R, Cole-Avent GA (2008) An introduction to technologies commonly used by college students. New Directions for Student Services 124: 3-17.

32. Geser H (2006) Are girls (even) more addicted? Some gender patterns of cell phone usage. Sociology in Switzerland: Sociology of the Mobile Phone.

33. Kuss DJ, Griffiths MD (2011a) Excessive online social networking: Can adolescents become addicted to Facebook? Education and Health 29(4): 68-71.

34. Kuss DJ, Griffiths MD (2011b) Online social networking and addiction-a review of the psychological literature. International journal of environmental research and public health 8(9): 3528-3552.
35. Hong FY, Chiu SI, Huang DH (2012) A model of the relationship between psychological characteristics, mobile phone addiction and use of mobile phones by Taiwanese university female students. Computers in Human Behavior 28(6): 2152-2159.

36. Leung L, Wei R (2000) More than just talk on the move: Uses and gratifications of the cellular phone. Journalism \& Mass Communication Quarterly 77(2): 308-320.

37. Tseng YY, Knockaert J, Verhoef ET (2013) A revealedpreference study of behavioural impacts of real-time traffic information. Transportation Research Part C: Emerging Technologies 30: 196-209.

38. Wu R, Rossos P, Quan S, Reeves S, Lo V, et al. (2011) An evaluation of the use of smartphones to communicate between clinicians: a mixed-methods study. Journal of medical Internet research 13(3): e59.

39. Whitlow ML, Drake E, Tullmann D, Hoke G, D Barth (2014) Bringing technology to the bedside: Using smartphones to improve interprofessional communication." Computers Informatics Nursing 32(7): 305-311.

40. Wickersham A, Salehi H, Pennathur P, Linson E, Are C, et al. (2015) Smartphones in the Improvement of Inter-Professional Communication. Journal of Hospital Medicine.

41. Mohan P, Padmanabhan VN, Ramjee R (2008) Nericell: rich monitoring of road and traffic conditions using mobile smartphones. In: Proceedings of the 6th ACM conference on Embedded network sensor systems, pp: 323-336.

42. White AG, Buboltz W, Igou F (2011) Mobile phone use and sleep quality and length in college students. International Journal of Humanities and Social Science 1(18): 51-58.

43. O’Neill M (2015) Smartphone Apps for People with Disabilities.

44. De Leo G, Leroy G (2008) Smartphones to facilitate communication and improve social skills of children with severe autism spectrum disorder: special education teachers as proxies. In Proceedings of the 7 th international conference on Interaction design and children, ACM, pp: 45-48.

45. Ling R, Yttri B (2002) 10 Hyper-coordination via mobile phones in Norway. Perpetual contact: Mobile communication, private talk, public performance, pp: 139.

46. Walsh SP, White KM, McD Young R (2010) Needing to 
connect: The effect of self and others on young people's involvement with their mobile phones. Australian journal of psychology 62(4): 194-203.

47. Chen YF, Katz JE (2009) Extending family to school life: College students' use of the mobile phone. International Journal of Human-Computer Studies 67(2): 179-191.

48. Wagner LA (2015) When Your Smartphone Is Too Smart for Your Own Good: How Social Media Alters Human Relationships. Journal of Individual Psychology 71(2): 114-121.

49. Nyiri K (2002) Towards a philosophy of M-learning. Proceedings of the IEEE Computer Society: Wireless and Mobile Technologies in Education (WMTE, 2002): 121124.

50. Katz J (2005) Mobile phones in educational settings. In: Nyiri K, (Eds.), A sense of place: The gobal and the local in mobile communication, Passagen, Vienna, pp: 305317.

51. Markett C, Sánchez IA, Weber S, Tangney B (2006) Using short message service to encourage interactivity in the classroom. Computers \& Education 46(3): 280-293.

52. Abachi HR, Muhammad G (2013) The impact of m-learning technology on students and educators. Computers in Human Behavior 30: 491-496.

53. Ahlquist J (2014) Trending now: Digital leadership education using social media and the social change model. Journal of Leadership Studies 8(2): 57-60.

54. Milrad M (2003) Mobile learning: Challenges, perspectives, and reality. In: Nyiri K, (Ed.), Mobile learning: Essays on philosophy, psychology, and education, Passagen, Vienna, pp: 151-164.

55. Lipschultz D (2000) On reinventing entertainment. Internet World 6(7): 72-84.

56. Geser H (2002) Sociology of the mobile phone. Unpublished manuscript, University of Zurich, Switzerland.

57. Mathews R (2004) The psychosocial aspects of mobile phone use amongst adolescents. In Psychology 26: 1619.

58. Ling R (2004) The mobile connection: The cell phone's impact on society. Elsevier.

59. Srivastava L (2005) Mobile phones and the evolution of social behaviour. Behaviour \& Information Technology 24(2): 111-129.
60. Wajcman J, Bittman M, Brown JE (2008) Families without borders: Mobile phones, connectedness and work-home divisions. Sociology 42(4): 635-652.

61. Wijaya IM (2013) The influence of brand image, brand personality and brand awareness on consumer purchase intention of apple smartphone. Jurnal EMBA: Jurnal Riset Ekonomi, Manajemen, Bisnis dan Akuntansi 1(4).

62. Campbell SW, Ling R (2009) Effects of mobile communication. In: Bryant J, Oliver MB, (Eds.), Media effects: Advances in theory and research, $3^{\text {rd }}$ (Edn.), Taylor and Francis, New York, pp: 592-606.

63. Park N, Lee S (2014) College students' motivations for Facebook use and psychological outcomes. Journal of Broadcasting \& Electronic Media 58(4): 601-620.

64. Plant S (2000) The effects of mobile telephones on social and individual life. Report commissioned by Motorola.

65. Carroll J, Howard S, Peck J, Murphy J (2002) A field study of perceptions and use of mobile telephones by 16 to 22 year olds. JITTA: Journal of Information Technology Theory and Application 4(2): 49.

66. Campbell SW, Russo TC (2003) The social construction of mobile telephony: an application of the social influence model to perceptions and uses of mobile phones within personal communication networks. Communication Monographs 70(4): 317-334.

67. Rosenberg M (1965) Society and the adolescent selfimage. Princeton University Press, Princeton, NJ.

68. Moody EJ (2001) Internet use and its relationship to loneliness. Cyberpsychology \& Behavior 4(3): 393-401.

69. Crocker J, Wolfe CT (2001) Contingencies of self-worth. Psychological Review, pp; 593-623.

70. Devitt K, Roker D (2009) The role of mobile phones in family communication. Children \& Society 23(3): 189202.

71. Ahmed I, Qazi TF, Perji KA (2011) Mobile phone to youngsters: Necessity or addiction. African Journal of Business Management 5(32): 12512-12519.

72. Manago AM, Taylor T, Greenfield PM (2012) Me and my 400 friends: The anatomy of college students' Facebook networks, their communication patterns, and wellbeing. Developmental Psychology 48(2): 369-380.

73. Padilla-Walker LM, Coyne SM, Fraser AM (2012) Getting a high-speed family connection: associations between family media use and family connection. Family Relations 
61(3): 426-440.

74. Nikhita CS, Jadhav PR, Ajinkya S (2015) Prevalence of mobile phone dependence in secondary school adolescents. Journal of Clinical and Diagnostic Research 9(11): VC06-VC09.

75. Pelling EL, White KM (2009) The theory of planned behavior applied to young people's use of social networking web sites. Cyberpsychology \& Behavior 12(6): 755-759.

76. Walsh SP, White KM, Young RM (2009) The phone connection: A qualitative exploration of how belongingness and social identification relate to mobile phone use amongst Australian youth. Journal of Community \& Applied Social Psychology 19(3): 225-240.

77. Zhang S, Jiang H, Carroll JM (2011) Integrating online and offline community through Facebook. In Collaboration Technologies and Systems (CTS), 2011 International Conference on, pp: 569-578.

78. Prohaska TR, Anderson LA, Binstock RH (2012) Public health for an aging society. JHU Press.

79. Albanesi C, Cicognani E, Zani B (2007) Sense of community, civic engagement and social well-being in Italian adolescents. Journal of Community \& Applied Social Psychology 17(5): 387-406.

80. Campbell SW, Kwak N (2011) Mobile communication and civil society: Linking patterns and places of use to engagement with others in public. Human Communication Research 37(2): 207-222.

81. Shah DV, Cho J, Eveland Jr WP, Kwak N (2005) Information and expression in a digital age: Modeling Internet effects on civic participation. Communication Research 32(5): 531-565.

82. Mihailidis P (2014) The civic-social media disconnect: exploring perceptions of social media for engagement in the daily life of college students. Information, Communication \& Society 17(9): 1059-1071.

83. Butt S, Phillips JG (2008) Personality and self-reported mobile phone use. Computers in Human Behavior 24(2): 346-360.

84. McCoy B (2013) Digital Distractions in the Classroom: Student Classroom Use of Digital Devices for NonClass Related Purposes. Faculty Publications, College of Journalism \& Mass Communications, Paper 71.

85. Löchtefeld M, Böhmer M, Ganev L (2013) AppDetox: Helping Users with Mobile App Addiction. In Proceedings of the 12th international conference on mobile and ubiquitous, Multimedia, ACM 13: 1-2.

86. Samaha M, Hawi NS (2016) Relationships among smartphone addiction, stress, academic performance, and satisfaction with life. Computers in Human Behavior 57: 321-325.

87. Kraut $\mathrm{R}$, Patterson $\mathrm{M}$, Lundmark V, Kiesler $\mathrm{S}$, Mukopadhyay $\mathrm{T}$, et al. (1998) Internet paradox: A social technology that reduces social involvement and psychological well-being. American Psychologist 53(9): 1017-1031.

88. Bachen C (2001) The family in the networked society: A summary of research on the American family. Center for Science technology society, Santa Clara University, CA.

89. Choliz M (2010) Mobile phone addiction: a point of issue. Addiction 105(2): 373-374.

90. Lanaj K, Johnson RE, Barnes CM (2014) Beginning the workday yet already depleted? Consequences of late-night smartphone use and sleep. Organizational Behavior and Human Decision Processes 124(1): 11-23.

91. Oulasvirta A, Rattenbury T, Ma L, Raita E (2011) Habits make smartphone use more pervasive. Personal And Ubiquitous Computing 16(1): 105-114.

92. Wang JL, Jackson LA, Zhang DJ, Su ZQ (2012) The relationships among the Big Five Personality factors, self-esteem, narcissism, and sensation-seeking to Chinese University students' uses of social networking sites (SNSs). Computers in Human Behavior 28(6): 2313-2319.

93. Mehdizadeh S (2010) Self-presentation 2.0: Narcissism and self-esteem on Facebook. Cyberpsychology, behavior, and social networking 13(4): 357-364.

94. Rosen LD, Carrier LM, Cheever NA (2013) Facebook and texting made me do it: Media-induced task-switching while studying. Computers in Human Behavior 29(3): 948-958.

95. Pearson C, Hussain Z (2015) Smartphone Use, Addiction, Narcissism, and Personality. International Journal of Cyber Behavior. Psychology and Learning 5(1): 17-32.

96. Addo A (2013) The adoption of mobile phone: how has it changed us socially?. Issues in Business Management and Economics 1(3): 47-60.

97. Salehan M, Negahban A (2013) Social networking on smartphones: When mobile phones become addictive. Computers in Human Behavior 29(6): 2632-2639. 
98. Sutter N, Holtgraves $T$ (2013) Perceptions of public mobile phone conversations and conversationalists. Telematics and Informatics 30(2): 158-164.

99. Walton SC, Rice RE (2013) Mediated disclosure on Twitter: The roles of gender and identity in boundary impermeability, valence, disclosure, and stage. Computers in Human Behavior 29(4): 1465-1474.

100. Lundquist AR, Lefebvre EJ, Garramone SJ (2014) Smartphones: fulfilling the need for immediacy in everyday life, but at what cost. International Journal of Humanities and Social Science 4(2): 80-89.

101. Taleb NN (2007) The Black Swan. The Impact of the Highly Improbable.

102. Caplan SE (2006) Relations among loneliness, social anxiety, and problematic Internet use. Cyberpsychology \& Behavior 10(2): 234-242.

103. Caplan SE (2010) Theory and measurement of generalized problematic Internet use: A two-step approach. Computers in Human Behavior 26(5): 10891097.

104. Bindley K (2011) When children text all day, what happens to their social skills? Huffington Post.

105. Elphinston RA, Noller P (2011) Time to face it! Facebook intrusion and the implications for romantic jealousy and relationship satisfaction. Cyberpsychology, Behavior, and Social Networking 14(11): 631-635.

106. Taleb NN, Antongiovanni D (2013) Antifragile: prosperare nel disordine. Il Saggiatore, pp: 550.

107. Hayes SC, Strosahl K, Wilson KG (1999) Acceptance and Commitment Therapy: An experiential approach to behavior change. Guilford Press, New York.

108. Hayes SC, Barnes-Holmes D, Roche B (2001) Relational frame theory: A post-Skinnerian account of human language and cognition. Plenum Press, New York.

109. Grover A, Kamins MA, Martin IM, Davis S, Haws K, etal. (2011) From use to abuse: When everyday consumption behaviors morph into addictive consumptive behaviors. Journal of Research for Consumers 19: 1-8.

110. Brown RIF (1991) Gaming, gambling and other addictive play. In: Kerr JH, Apter MJ, (Eds.), Adult play: A reversal theory approach, Swets \& Zeitlinger, Amsterdam, pp: 101-118.
111. Brown RIF (1993) Some contributions of the study of gambling to the study of other addictions. In: Eadington WR, Cornelius JA, (Eds.), Gambling behavior and problem gambling, NV: University of Nevada, Reno, pp: 241-272.

112. Moderato P (2010) Interazioni Umane. Manuale introduttivo alla psicologia, Franco Angeli, Milano.

113. Griffiths M (1999) Internet addiction: Internet fuels other addictions. Student Br Med J 7: 428-429.

114. Alavi SS, Ferdosi M, Jannatifard F, Eslami M, Alaghemandan $\mathrm{H}$, et al. (2012) Behavioral addiction versus substance addiction: Correspondence of psychiatric and psychological views. International Journal of Preventive Medicine 3(4): 290-294.

115. Roberts JA, Pirog III SF (2012) A preliminary investigation of materialism and impulsiveness as predictors of technological addictions among young adults. Journal of Behavioral Addictions 2(1): 56-62.

116. Duggan M (2015) Mobile Messaging and Social Media. Pew Research Center.

117. Kwon M, Kim DJ, Cho H, Yang S (2013) The Smartphone Addiction Scale: Development and Validation of a Short Version for Adolescents. PloS One 8(12): e83558.

118. Leeman RF, Potenza MN (2013) A targeted review of the neurobiology and genetics of behavioural addictions: an emerging area of research. The Canadian Journal of Psychiatry 58(5): 260-273.

119. Hong SB, Zalesky A, Cocchi L, Fornito A, Choi EJ, et al. (2013) Decreased functional brain connectivity in adolescents with internet addiction. PloS one 8(2): e57831.

120. Rella M, Fusco V, Fasciani P (2012) Gioco d'azzardo patologico: sperimentazione di un modello d'intervento presso il Ser. T. di Chieti. Italian Journal on Addiction 2(34).

121. Cozzolino E, Zita G (2017) Approcci clinici al disturbo da gioco d'azzardo. Mission-Open Access.

122. Chapman S, Schofield WN (1998) Lifesavers and Samaritans: emergency use of cellular (mobile) phones in Australia. Accident Analysis \& Prevention 30(6): 815819. 